\title{
Renal prostacyclin influences renal function in non-azotemic cirrhotic patients treated with furosemide
}

\author{
Jorge Quiroga', José M. Zozaya ${ }^{1}$, Pablo Labarga², Carlos M. Rodríguez-Ortigosa', \\ Alfredo Milazzo ${ }^{2}$ and Jesús Prieto' \\ 'Deparimenr of Internal Medicine, Universily Clinic of Navarra, Pamplona, and 'San Millan Hospital, Logrono, Spain
}

(Received 15 December 1989)

The influence of prostaglandins on renal function changes induced by furosemide was analyzed in 21 non-azotemic cirrhotic patients with ascites. Patients were studied in two periods of 120 min immediately before and after furosemide infusion (20 mg, ev). Furosemide caused an increase in creatinine clearance in 15 patients (group A: $99 \pm 7$ vs. $129 \pm 5 \mathrm{ml} / \mathrm{min}$; mean $\pm S$. E.) and a reduction in the remaining six (group $B: 102 \pm 13$ vs. $71 \pm 9 \mathrm{ml} / \mathrm{min}$ ). Parallel changes were observed in the urinary excretion of 6-Keto-prostaglandin $-\mathrm{F}_{1 x}$ (metabolite of renal prostacyclin) which augmented after furosemide in 14 of the 15 patients from group $A(478 \pm 107 \mathrm{vs} .1034 \pm 159 \mathrm{pg} / \mathrm{min}, p<0.001)$ and decreased in all patients from group B (1032 \pm 240 vs. $\left.548 \pm 136 \mathrm{pg} / \mathrm{min}_{1} p<0.05\right)$. In contrast, the urinary excretion of prostaglandin $E_{2}$ was stimulated by furosemide in all patients (group A, $92 \pm 19$ vs. $448 \pm 60 \mathrm{pg} / \mathrm{min}, p<0.001$; and group B, $209 \pm 63 \mathrm{vs.} 361 \pm 25 \mathrm{pg} / \mathrm{min}, p<$ 0.05 ). In all of the patients furosemide-induced changes (post- minus pre-furosemide values) in creatinine clearance were closely correlated in a direct and linear fashion with those in 6-Keto-prostaglandin- $\mathrm{F}_{1 a}(r=0.74 ; p<0.001)$. These changes were associated with a higher furosemide-induced natriuresis in group $A$ than in group $B$ (641 \pm 68 vs. $302 \pm 46$ $\mu \mathrm{mol} / \mathrm{min}, p<0.001)$. In the basal period urinary 6 -Keto-prostaglandin- $\mathrm{F}_{\mathrm{Ia}}$ was significantly higher $(p<0.05)$ in group $\mathrm{B}$ than in group $A$, no differences being found in the remaining parameters, including plasma renin activity (group $A, 9.7 \pm$ 2.6 vs. group B, $12.0 \pm 3.9 \mathrm{ng} / \mathrm{ml}$ per h) and urinary sodium output (group A, $30.1 \pm 10.6$ vs. group B, $11.8 \pm 3.5 \mu \mathrm{mol} /$ min). In summary, our results suggest that renal prostacyclin metabolism influcnecs renal rcsponse to furosemide in cirrhotic patients.

The mechanisms underlying the development of azotemia in some cisrhotic patients with ascites undergoing sustained furosemide therapy have not been fully defined (16). Although furosemide induces volume depletion and angiotensin II generation that can justify azotemia in some cases $(5,6)$, profound impairments in renal function and renal plasma flow have been demonstrated immediately after a single dose of furosemide in patients in which these two alterations were absent (17). These complications cannot be predicted from clinical or analytical data and they seem to be unrelated to the degree of hyperreni- nism or to the status of renal function before diuretic challenge (7). Furthermore, recen: data indicate that prostaglandin- (PG) $E_{2}$ and thromboxane $A_{2}$ exert little or no influence on changes in renal function and renal hemodynamics observed in cirrhotics with ascites immediately after furosemide administration $(7,8)$. However, furosemide-induced renal vasodilation is absolutely abolished by inhibitors of $\mathbf{P G}$ synthesis $(9,10)$.

Prostacyclin is a powerful renal vasodilatory PG, which plays a crucial role in protecting renal function against vasopressor agents in ascitic patients (11). This substance.

Correspondence: Professor Dr. Jesús Prieto, Department of Internal Medicine. University Clinic of Navarra, Pamplona 31080, Spain. 
whose renal synthesis is increased by furosemide in parients with Jiver cirrhosis (8), has been found to be in-

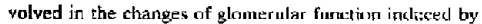
this diuretic in healthy animals (12). In this study we analyzed whether renal prostacyclin influences the response of renal function to a single dose of $i . v$. furosemide in nonazotemic cirrhotics with ascites.

\section{Pattents asd Methods}

Twenty-one patiente (18 men. thres wumen) with cirrhosis, ascites and preserved renal function were studied. The diagnosis of cirrhosis was established by liver biopsy andior laparoscopy, and the presence of ascites was proved by diagnostic paracentes is in al cases. Patients with gastrointestinal bleeding, hepatic encephalopathy, infeutigl, pasi or poesent histury ur cardlovaseular disease, diabetes mellitus, neoplasia, functional renal failure or clinical or analytical data of parenchymal renal disease were not included in the study.

\section{Protocol of siudy}

In the 4 days before the study, patients were giveil a diet containing 60 mmol/day of sudium and were maintained on bed rest, and therapy with diuretics, PG synthesis inhibitors, vasoactive substances or any other drag able to modify renal hemodynamics or function was withdrawn. Indeed, no patien: taking spironolactone, glucocorticoids of non-steroidal antiinflanmatory drugs in the preceding 7 days was included in the study.

After an overnight fast and bed rest, patients were studied in the morning of the fifth day. After bladder evacuation, $5 \mathrm{cc}$ of water/kg c.f body weight were given orally at 8 a.m. to maintais urine flow. All urine was collected in two consecutive periods of 2 h immediativy before (8-10 a.m.) and after (10 12 a.m.) the intravenous administration of $20 \mathrm{mg}$ of furosemide (Seguril, Hoechst Iberied Labs., Spain). Bloud samples obtained at 9 and 11 a.m., and urine aliquots of each period were used for analytical determinations. In all patients urinary vol ime (UV), urinary sodium excretion (UNaV), creatinine clcarance (CCr), fractional sodium excretion (FENa), and the urinar) excretion of $\mathrm{PGE}_{2}\left(\mathrm{UPGE}_{2}\right)$ and of 6-Keto-prostaglandin- $F_{1 c}$ (U-6-Keto-PGF ${ }_{1 a}$ ), the stable urinary inetabolite of segal prostacyclin, were determined in both periods of the study, while plasma renin activity (PKA) was measured only in the iasal one.

\section{Analytical determintations}

Electrolytes and creatinine were measured in serum and urine by flame photometry and Jaffe's chromogen reaction, respcctively. Liver function parameters were determined by standard methods. Blood for PR $\Lambda$ was collectul in ENTA, immediately processec at $4{ }^{\circ} \mathrm{C}$ and the sera stored at $-40^{\circ} \mathrm{C}$. PRA was estimated by radioimmunoassay for angiorensin I (Cea Sorin. France). Urine samples for $\mathrm{PG}$ quantitation, were collected on ice in lysineacetylsalicylate and frozen at $-40^{\circ} \mathrm{C}$ until use. To determine UPGE and U-6-Keto-PGF 1 , polas lipids were extracted from urine aliquots $(10 \mathrm{~m}$ ) , on disposable $\mathrm{C}-18$ cartridges (Sep-Pak. Waters Assos., Milford, MA. U.S.A.) (13), heing hoth metabolites measured in the resultan eluates by specific radioimmunoussays as previously described (14). Mear recoveries for $\mathrm{PGE}_{2}(82 \pm$ $4 \%)$ and for $\mathrm{h}-\mathrm{Keto}-\mathrm{PGF}_{1 \pi}(79 \pm 3 \%)$ were calculated by the addition of labelled $\mathrm{PGE}_{2}$ and $6-\mathrm{K}_{\text {eto-PGF }}$, to five urine aliquots before prowessing. These mean values were used for corrections in all samples. In I1 normal subjects unuter a sirnllar protocol. mean vatues of $0-6$-Keto-PGF $F_{1 a}$ and []$-\mathrm{PGE}_{2}$ were $191.8 \pm 28.4$ and $272 \pm 83.1 \mathrm{pg} / \mathrm{min}$, respectively. The administration of indomethacin (100 $\mathrm{mg}$ (wice the day before urine collection) to these controls significantly inhibited the urinary excretion of both metabolites $(56.7 \pm 5.2 \%, p<0.01$; and $63 \pm 6.4 \%, p<$ 0.01, respectively). Tritiated 6-Keto-PGF $\mathrm{I}_{2}$ and $\mathrm{PGE}_{2}$ (110) okl dpm) were used as standards. Antiserum againsc

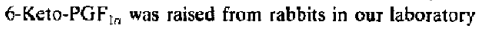
by the method of Kirton et al. (15), with its binding characteristics and cross-reactivities as reported elsewhere (14). Antiserum for $\mathrm{PGE}_{2}$ was abtained from the Pasteur Institute (France), and its cross-reactivities with other prostanoids were as follows: $0.11 \%$ with PGF $_{2 a} ; 0.01 \%$ with $\mathrm{PGF}_{1 \alpha}$, and less than $0.01 \%$ with $\mathrm{TxB}_{2}, \mathrm{PGD}_{2}$ and 6 Keto-PGF a . All samples in a single bach were determined in duplicate to minimize errors due to interassay yariation.

Sratisficol analyois

P.esults are expressed as mean \pm S.E. Comparicarc he twoer groups were made by variance analysis. The Student 1 -test for paired data or the non-parametric Wilcoxon test were used for intragroup comparisons as indicated. Regression analysis was performed by the least-squares method.

\section{Results}

Pattents were retrospectively divided into two groups according to the furosemide-induced change in $\mathrm{CCr}$ (postminus pre-furosemide values). In 15 patients (group A), CCr increased in response to turosemide (mean change: $30.3 \pm 5.6 \mathrm{ml} / \mathrm{min} ;+30.6 \%$ ), whereas in the remaining 


\section{TABLE I}

thatacteristics of cierhatic patienls with ascites inciuded in the sludy

\begin{tabular}{|c|c|c|c|c|c|c|c|c|}
\hline & $\begin{array}{l}\text { Agc } \\
\text { (ycars) }\end{array}$ & $\begin{array}{l}\text { Scx } \\
\text { (M/F) }\end{array}$ & $\begin{array}{l}\text { Serum } \\
\text { nlbumin } \\
\text { (g/dl) }\end{array}$ & $\begin{array}{l}\text { Serum } \\
\text { bilirubin } \\
\text { (mg'dl) }\end{array}$ & $\begin{array}{l}\text { Prolhrombir } \\
\text { time }(\%)\end{array}$ & $\begin{array}{l}\text { Serum } \\
\text { sodium } \\
\text { (mmoll) }\end{array}$ & $\begin{array}{l}\text { Plasma renin } \\
\text { activity } \\
\text { (ng'ml per h) }\end{array}$ & $\begin{array}{l}\text { Mean arterial } \\
\text { pressure } \\
\left(\mathrm{mm} \mathrm{Hg}_{\mathrm{g}}\right)\end{array}$ \\
\hline Group $A(n=15)$ & $59.3 \pm 3.3$ & $13 / 2$ & $3.13 \pm 0.13$ & $2.58 \div 0.62$ & $73.8 \pm 5.2$ & $132.9 \pm 0.9$ & $9.73 \pm 2.55$ & $81.4 \pm 3.4$ \\
\hline Group B $(n=0)$ & $\$ 2.3 \pm 3.8$ & $5 / 1$ & $3.10 \pm 0.32$ & $4.95 \pm 1.14$ & $67.5 \pm 5.5$ & $130.2 \pm 0.9$ & $12.01 \pm 3.90$ & $79.1 \pm 3.6$ \\
\hline
\end{tabular}

Results are mean \pm S.E. No significant differences were found between groups.

six (group B) changes of $\mathrm{CCr}$ were negative (mean change: $-31.5 \pm 6.3 ; \mathrm{ml} / \mathrm{min} ;-30.8 \%$ ).

Mean age (A, $59.3 \pm 3.3 ; B, 52.3 \pm 3.8$ years; N.S.), male/female ratio (A, $13 / 2 ; B, 5 / 1$ ), etiology of cirrhosis (A, 12 alcoholic, three post-necrotic; B, five alcoholic, one post-necrotic), mean arterial pressure (A, $81.4 \pm 3.4$; B. $79.1 \pm 3.6 \mathrm{~mm} \mathrm{Hg}$; N.S.), as well as basic analytical parameters and PRA levels (Table 1) were similar in both groups.

\section{Renal finction paramelers}

Tahle 2 summarizes mean values of renal function parameters before and after furosemide in both groups.

Before furosemide no significant differences were found between groups in CCr, UNaV, UV nor PENa, although UNaV and FENa tended to be lower in group $B$ than in group $A$. In the post-furosemide period, mean

\section{TABLE 2}

Harameters of renal function beforc (pre-) and afler (post-) furosemide administration in non-azotemic cirrhotic patients with ascites divided according to their positive (group A) or negative (group B) change in creatinine clearance in response to furosernide

\begin{tabular}{|c|c|c|c|}
\hline & & $\begin{array}{l}\text { Group A } \\
(n=15)\end{array}$ & $\begin{array}{l}\text { Group B } \\
(n=6)\end{array}$ \\
\hline $\begin{array}{l}\text { Creatinine cle arance } \\
\text { (mlimin) }\end{array}$ & $\begin{array}{l}\text { pre- } \\
\text { post- }\end{array}$ & $\begin{array}{r}99.9 \pm 7.1 \\
129.3 \pm 5.3^{n}\end{array}$ & $\begin{array}{c}102.2 \pm 13.3 \text { (N.S.) } \\
70.7 \pm 9.3^{0 .}\end{array}$ \\
\hline $\begin{array}{l}\text { Urine volume } \\
\text { (ml/min) }\end{array}$ & $\begin{array}{l}\text { pre- } \\
\text { post- }\end{array}$ & $\begin{array}{l}0.62 \pm 0.14 \\
6.34 \pm 0.56^{14}\end{array}$ & $\begin{array}{l}0.91 \pm 0.21 \text { (N.S.) } \\
3.82 \pm 0.51^{\mathrm{b}, *}\end{array}$ \\
\hline $\begin{array}{l}\text { Urine sodium } \\
\text { excretion } \\
\text { (urnol/min) }\end{array}$ & $\begin{array}{l}\text { pre- } \\
\text { prisi- }\end{array}$ & $\begin{array}{c}30.1 \pm 10.6 \\
6709 \pm 750^{6}\end{array}$ & $\begin{array}{l}11.8 \pm 3.5 \text { (N.S.) } \\
313.8+48.1^{2 . * *}\end{array}$ \\
\hline $\begin{array}{l}\text { Fractional sodium } \\
\text { excretion (\%) }\end{array}$ & $\begin{array}{l}\text { pre- } \\
\text { post- }\end{array}$ & $\begin{array}{l}0.20 \pm 0.06 \\
3.85 \pm 0.33^{b}\end{array}$ & $\begin{array}{l}0.10 \pm 0.03 \text { (N.S.) } \\
3.50 \pm 0.41^{\mathrm{b}} \text { (N.S.) }\end{array}$ \\
\hline
\end{tabular}

Resuits are mean \pm S.E.

Intragroup comparisons (Student -test for paired data):

ip $<0.01, b_{p}<0.001$.

Group A vs. group B: " $p<0.05 ; " * p<0.001$

N.S., not significant. values of these parameters were significantly higher in group A than in group B, with the rxception of FENa which was similar in both groups.

\section{Urinary excretion of renal $P G$ metabolites}

Individual values of U-6-Keto-PGF 19 and $\mathrm{UPGE}_{2}$ in the two periods of the study are represented in Figs. 1 and 2 , respectively.

In the basal period, U-6-Keto-PGF $\mathrm{F}_{1 \alpha}$ was significantly lower in group $A$ than in group $B$, whereas no significant differences were found in $\mathrm{UPGE}_{2}$ levels, although it tended to be higher in group $B$. In response to furosemide, UPGE ${ }_{2}$ increased in all patients, with post-furose-

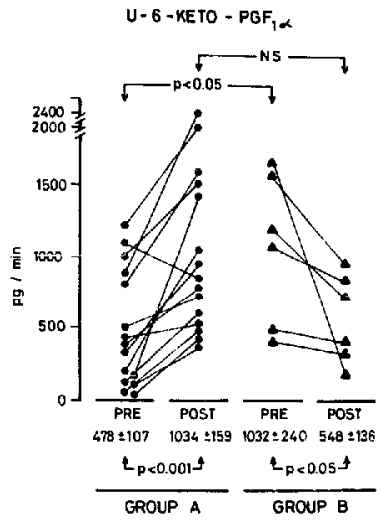

Fig. 1. Urinary excrelion of 6-Keto-prostaglandin- $F_{1 u}$ (U-6-Keto$\mathrm{PGF}_{\mathrm{Iq}}$ ) before and after furosemide administration ( $20 \mathrm{mg}$, ev) in non-azotenic cirrhotic patients with escites, showing, respectively, an increase (group A) or decrease (group B) in creatinine clearanee in response to furosemide. 


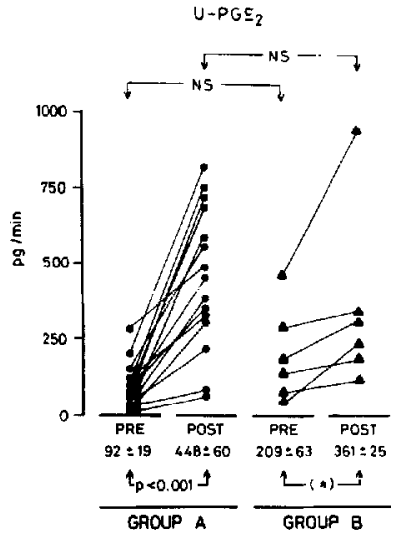

Fig. 2. Urinary excretion of prosiaglandin $\mathrm{E}_{2}$ vefore and after furosemide administration (20 mg, ev) in non-azotemic cirrhotic patients with ascites showing, respectively, an increase (gresup $A$ ) or decrease (group B) in creatinine clearance in response to furosemide. Comparisons between groups are in the figure. Intragroup comparisons (Student $l$-test fot paired data): (a) $p<0.001,(\cdot) 0.05<p<0.1$ and $p<0.05$ with the non-parametric Wilcoxon test.

mide levels significantly higher than those in the basal period in both groups. However, U-6-Keto-PGF $1 \alpha$ was increased after furoseniide in 14 patients, all of them from group $A$. In the remaining seven patients (one from group $A$ and all from group B) this metabelite decreased after furosemide. As a result, as compared with baseine levels, mean values of $U-6-K e t o-P G F$, were significantly increased and decreased in groups $A$ and $B$, respectively, in response to furosemide.

The ahonlute furosemide-induced response (obtained by subtracting pre- from post-furosemide values in each

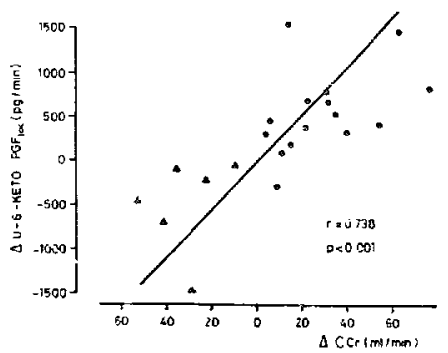

Fig. 3. Correlation between the furosemide-indiced increases in ereatinine clearance ( $\Delta \mathrm{CCr}$ ) and in the urinary axcretion of 6 -Keto-

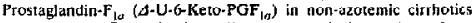
with ascites. (Q) and $(\Delta)$ indicate, respectively, patients from groups $\mathbf{A}$ and $\mathbf{B}$.

patient) in the urinary excretion of PG as well as in renal function parameters is showed in Table 3.

Finally, when all patients wcrc taken tugether, furosemide-indured changes in $\mathrm{CCr}$ were closely correlated with thuse in U.6-Keto-PGF ${ }_{1 a}(r=0.75 ; p<0.001)$ (Fig. 3) and, to a lesser extent, with those in U-PGE $2 r=0.51$; a $<0.05$ ). In addition, the changes in each metabolite correlated anong them in a linear and direct fashion $i r=$ $0.55 ; p<0.05$ ). However, a multiple correlation obsained by plotting furosemide-induced changes in $\mathrm{CCr}$ against those in U-6-Keto-PGF ${ }_{1 x}$ and UPGE $_{2}$, disclosed that only the levels of the former metabolite influenced significantly changes in $\mathrm{CCr}$.

\section{Discussion}

This study was designed to eyaluate whether the atute effects of furosemide en renal function in non-azot $t$ nnit cirshotics with ascites are influenced by repal prostacyclin. Renal proslacyclin synthesis was assessed timough

\section{TABLE 3}

Furosemide-induced changes in parameters of renal function and urinary prostaglandin excrezion in non-azotemic cirrhotic patients with ascites divided according to their positive (Group A) or negative (Group B) change in creatinine clearance

\begin{tabular}{|c|c|c|c|c|c|c|}
\hline & $\begin{array}{l}\text { Creatining } \\
\text { clearance }(\mathrm{ml} / \mathrm{min})\end{array}$ & $\begin{array}{l}\text { Urine volume } \\
\text { (mil/min) }\end{array}$ & $\begin{array}{l}\text { Urinary sodium } \\
\text { (mmol/min) }\end{array}$ & $\begin{array}{l}\text { Fractional sodium } \\
\text { excretion }(\%)\end{array}$ & $\begin{array}{l}\mathrm{UPGE}_{2} \\
\left(\mathrm{pg}^{\prime} \mathrm{min}\right)\end{array}$ & $\begin{array}{l}\text { U-6-Keto-PGF } \\
\text { (pg/min) }\end{array}$ \\
\hline Group $A(n=15)$ & $30.3 \pm 5.6$ & $5.72 \pm 0.51$ & $641 \pm 68$ & $3.65 \pm 0.29$ & $356 \pm 55$ & $556 \pm 122$ \\
\hline Groilp $B(n=6)$ & $\begin{array}{l}(-) 31.5 \pm 6.3^{(*)} \\
p<0.00 !\end{array}$ & $\begin{array}{l}2.90 \pm 0.40 \\
p<0.05\end{array}$ & $\begin{array}{l}302 \pm 46 \\
p<0.01\end{array}$ & $\begin{array}{l}3.40 \pm 0.40 \\
\text { N.S. }\end{array}$ & $\begin{array}{l}152 \pm 74 \\
0.05<\beta<0.1\end{array}$ & $\begin{array}{l}(-) 484 \pm 237 \\
p<0.04 !\end{array}$ \\
\hline
\end{tabular}

Results (mean \pm S.E.) were obtained by subtracting pre. trom post-furosemide values in each patient. The Student t-lest was uscd for comparisons. N.S. , not significant.

i+1 Classification criterium. 
the measurement of U-6-Keto-PGF la . Although a fraction of this urinary metabolitc probably arises from prerenal sources, its quantitation is a widely accepted metiod for mensuring the production of prostacyclin by the kidneys, since several studies (16-18), including recent data from cirrhotic patients (19). support a markedly predominant renal origin for the $\mathrm{U}-6-$ Keto-PGF Iu $_{\text {present in }}$ urine.

Present results confirm earlier observations and demonstrate a.i acute impairment of renal funclion in some cirllotic pitients with ascites following furosemide administration (7). Other studies have pointed out that the renovascular effects of furosemide are partially dependent on the stimulation of the renal synthesis of vasodilatory prostaglandins induced by this diuretic (9). Recently, no differences were observed in pre- or post-furosemide levels of $\mathrm{UPGE}_{2}$ between cirrhotic patients showing increases or deci eases of renal plasma flow after the diuretic. Thus, a primary role for $\mathrm{PGE}_{2}$ in the hemodynamic effects of furosenide secms to be unlikely. In contrast, the parallel changes oi CCr and U-6-Keto-PGF ${ }_{I a}$ observed after furosemide administration in this study, suggest that renal prostacyclin may modulate, at least in part, the acute glomerular effects of this diuretic in cirrhotic patients.

Associated decreases of rena! plasma flow and glomerular filtration rate have been demonstrated in some cirrhotics with ascitcs immediatcly after furosemide administration (7). It is conceivable that the fall of $\mathrm{CCr}$ observed in patients from group $B$ in this study is secondary to a decrease in renal blood flow. In cirrhotic patients with ascites renal blood flow and $\mathrm{CCr}$ depend on an equilibrium between vasoconstrictor and vasodilatory forces acting on the kidney (11). Vasoconstrictor agents were not measured afiei furcsemide in our study. However, it may be rasse abiy assumed that group B patients were exposed to increased vasoconstrictor influences since they exhibited mean basal levels of plasma renin activity exceeding the upper normal limit by about 5 times, and furosemide has been shown to increase the release of pressor agents shortly after its administration (12). In such a situation, a drop in renal vasodilators should be expected to determine an imptirment of both renal blood flow and renal function, as was found in patients from group $B$ in which hoth $\mathrm{CC}_{\text {and }} \mathrm{U}-6 \cdot \mathrm{K}$ - to. $\mathrm{PGF}_{\mathrm{la}}$ were reduced in the post-furosemide period. On the other hand, in patients from group A, whose plasma renin activity levels were also supranormal before diuretic challenge, $\mathrm{CCr}$ was raised after furosemide, in association with a marked increase in U-6-Keto-PGF $1 a$. Overall, these data are in agreement with the idea that renal vasodilatory prostaglandins contribute to maintain renal function in cirrhotic patients by counteracting the effects of pressor hormones (11).
Non-steroidal antiinflammatory drugs, whose primary action is the inhibition of prostaglandin synthesis, have been shown to impair renal function in cirrhotic patients with ascites and increased vasoconstrictor tone $(11,20,21)$. Thus, nur results suggest that the detericration of $\mathrm{CCr}$ in patients from group $\mathrm{B}$ may reflect a shift in renal vasomotor equilibrium toward vasoconstriction. secondarily to the drop in renal prostacyclin synthesis.

Although unlikely, the possibility that changes in $\mathrm{CCr}$ might induce paralsel modifications of renal prostacyclin synthesis or the urinary washout of U-6-Keto-PGF ${ }_{1 \alpha}$, cannot be exciuced. Thus, this alternate explanation should he kept in mind to interpret findings in this study.

lncreases of both $\mathrm{UPGE}_{\mathbf{2}}$ (all patients) and U-6-Keto$\mathrm{PGF}_{1 a}$ (group A) are consistent with the well-known stimulatory effect of furosemide on the cyclooxygenase pathway of arachidonic acid (10). The mechanisms leading to the isolated drop in U-6-Keto-PGF $1 \alpha$ levels in patients from group $B$ cannot be ascertained from data in this study. These patients showed basal levels of U.6.Keto. $\mathrm{PGF}_{1 a}$ significantly higher than those in group $\mathrm{A}$. Whether this previous increase in activity of the prostacyclin synthesizing pathway may predispose it to failure after furosemide administration remains to be investigated.

Cn the other hand, mechanisms unrelated to renal prostaglandins might contribute, to some extent, to changes in $\mathrm{CCr}$ after furosemide. This drug inhibits the tubuloglomerular feedback mechanism which is involved in the maintenance of renal perfusion pressure during changes in arterial pressure (22). Early and transitory changes in arterial pressure have been observed after furosemide administration in patients with congestive cardiac failure (23). Although similar events remain to be verified in cirrhotic patients (24), it is possible that variations in arterial pressure in the post-furosemide period, might induce coupled changes in $\mathrm{CCr}$ in the presence of an impaired tubuloglomerular feedhack mechanism (22).

In summary, this study suggests that renal prostacyclin may play a major role in mediating the glomerular effects of furosemide in cirrhotic patients with ascites and that a drop in its synthesis may contribute to the acute impairment of renal function occurring in some of these patients after furosemide administration.

\section{Acknowledgements}

This work was supported by a grant from Gobierno Yasco and grant PA86-0084 from the Comisión Asesora de Investigación Científica y Técnica. The authors are grateful to Carmentxu Miqueo, Celia Asensio, Clotilde Wilhelmi and Edurne Elizalde for their technicd assistance. 


\section{References}

I Sherlock S. Asciles formation and its management. Scand J Gastroenterol 1970: 7 (Suppl): 9-15.

2 Rodes J. Bosch J, Arroyu V. Clinical types znd drug therapy of renal impairment in cirrhosis. Postgrad Med j 1975: 51 : $492-7$.

3 Spino M. Setlers EM. Kaplan HL, Stapicton C, Mac Leod SM. Adverse biochemical and clinical consequences of furosemide administration. Can Med Assoc .5 1978; 118: 1513-8.

4 Linas SL. Anderson RJ, Miller PD. Schrier RW. The rational use of diure lics in cirrhosis. In: Epstein M, ed. The Kidney in Liver Disedse. 2nd Edn. New York: Elsevier Biomedical, 1983: 555-67.

5 Lieberman FL. tto S. Reynolds TB. Effective plasma volume in cirrhasis with ascites. Evidence that a decreased value does not account for renal sodium reterlion, a spontaneous seduction in glomerular filtration rate (GFR), and a fall in GFR during drug. induced diuresis. J Clin Invest 1969; 48: 975-81.

6 Wilkinson SP. Wheeler PO, Bernardi M, Smith IK, Williams R. Diuretic-induced renal impairment without wolume depletion in cirrhosis: changes in the renin-angiotensin system and the eflect of $\beta$-adrenergic blockade. Postgrad Med J 1979; $55: 862-\%$.

7 Daskalopoulos $G$, Laffi $G$. Morgan T, et al. Immediate eifects of furosemide on renal hemodynamics in chronic liver disease with asciles. Gastroenterology 1987: 92: 1859-63.

8 Pinzani $M_{*}$ Laffi G, Meacci E. La Villa G, Cominelli F. Gentiliti $P$. Intrasenal thromboxane $A_{2}$ generation reduces the furosemide-induced sodium and water diuresis in citrhosis with ascites. Gastroenterology 1988; 95: 1081-7.

9 Planas R, Arroyo V, Rimola A, Pérez- $\Lambda$ yuso RM, Rodés 1 . Ace tylsalicylic acid suppresses the renal hemodynamic effect and re. duces the diuretic action of furosemide in cirrhosis with ascites. Gastroenterology 1983: 84: 247-52.

10 Gerber JG. Role of prostaglandins in the hemodynamic and tu. bular effects of furose mide. Fed Proc 1983; $42: 1707-10$

11. Arroyo V, Gines P, Rimola A, Gaya J. Renal function abnormalities, prostaglandins, and effects of nonsteroidal anti-inflammatory drugs in cirrhosis with ascites. An overview with emphasis on pathogenesis. Am J Med 1986; 81 (Suppl 2B): 104-22.

12 Wilson TW, Boyd Loadholt C. Privitera PJ, Halushka PV. Furosemide increases urine 6-keto-prostaglandin $\Gamma_{\text {lat. }}$. Relation to na. triuresis. vasodilation, and renin release. Hypertension 1982;4: $634 \ldots 4$ !:

13 Powel: WS. Rapid extraction of arachidonic acid metabolites from butogical samplex uxing actadecylsilyl silica. Methods En7ymol 1982: 86: $467-7$.

14 Guarnet C. Colina I. Guarner F. Corzo J. Prieto J, Vitardel1 F. Renal prostaglandins in cirrhosis of the liver. Clin Sci 1986; 70: $477-84$.

15 Kirtun KГ, Cornerte IC, Barr KL. Characterization of antibody to pros!aglandin $\mathrm{F}_{2 \tau^{\prime}}$ Biochem Biophys Res Commun 1972; 47 : 903-9.

if Rosenktantz B. Fischer C, Weimer KE, Frülich JC. Metabolism of prostacyclin and 6-keto-prostaglandin $F_{1, a}$ in man. J Biol Chem .980: 255-10194-8.

17 Fitzgerald GA, Pedersen AK, Patrono C. Analysis of prostacyclin and thromboxane biósynthesis in cardiovascular disease. Cirtulaion 19:3; 67: 1174-7.

Is Patrono C. Pugliese F. Ciabatonj G, et al. Evidence for a ditect stimulatory effect of prostacyclin on tenin relęase in man. $J \mathrm{Clin}$ Invest 1982; 69: $231-9$.

19 Guarner F, Guamer C. Prieto J, ct al. Increated synthesis of systemic pros:acyclin in cirrhotic patients. Gastroente rology 1986; 917: $6 r 7-94$

20 Zipser RD. Husis JC, Speckast PF, Ziu PK, Horton R. Prosta. gandins: modulators of renal furction and pressor resistance in chronic liver disease. J Clin E-Jocrinol Metab 1979: 48: 895-900.

21 Zipser RD. Kerlin P, Hoefs J, Zia PK. Barg A. Urinary kallikrein excreuon in cirrhosis: relationship to other vasoactive sysIcms. Am J Gestrocntcrod 1981; $75: 183-7$.

22 Sánchez-Ferrer CF, Roman RJ, Harder DR. Pressure-dependent contraction of rat juxtamedullary afferent arterioles. Circ Res 1989:64: 790-8.

23 Francis GS, Siegel RM, Goldsmith SR, Olvari MT, Levine TB, Cohn JN. Acute yasoconstzictor response to intravenous furosemide in pationts with chronic congestive heart failure. Acrivation of the neurohumoral axis. Ann Intern Med 1985; 103: 1-6.

24 Cereda JM, Roulot D, Braillon A, Moreau R, Koshy A, Lebrec D. Reduction of portal pressure by acute administration of furosemide in patienis with alcoholic cirrhosis. J Ficpatol 1989; 9 : $246-51$ 